\title{
Myelin Sheath Survival following Axonal Degeneration in Doubly Myelinated Nerve Fibers
}

\author{
Grahame J. Kidd a and John W. Heath \\ The Neuroscience Group, Faculty of Medicine, The University of Newcastle, New South Wales, 2308, Australia
}

\begin{abstract}
Axonal contact plays a critical role in initiating myelin formation by Schwann cells. However, recent studies of "double myelination" have indicated that myelin maintenance continues in Schwann cells completely displaced from physical contact with the axon. This raises the possibility either that diffusible trophic factors are produced by the axon, or that the axon is not required for myelin maintenance by these displaced Schwann cells. To test these hypotheses, the axons involved in double myelination in the mouse superior cervical ganglion (SCG) were transected surgically by a transganglionic lesion. The inferior pole of the SCG was resected to limit axonal regeneration. This method produced a typical Wallerian pattern of degeneration in the superior pole, without compromising the blood supply or introducing nonspecific trauma. EM analysis at 1 and $5 \mathrm{~d}$ postoperatively showed that initially the axon degenerated, followed by breakdown of the inner myelin sheath. In those configurations where the outer Schwann cell was only partly displaced from the axon, the outer myelin sheath degenerated simultaneously. However, in completely displaced internodes the outer sheath survived degeneration of the axon and inner sheath. Outer internodes remained intact for at least 5 weeks after transection (the longest time point in this study), at which time they enclosed reorganized processes of the inner Schwann cells, their basal lamina, and numerous collagen fibrils. Axonal regeneration within surviving outer internodes was rare and was characterized by the development of typical Remak ensheathment by the inner Schwann cells. We conclude that in the mouse SCG, myelin maintenance does not depend on the continued presence of the axon. These data suggest further that myelin breakdown in Wallerian degeneration may be initiated by mechanisms other than absence of a viable axon.
\end{abstract}

Numerous studies have identified the axon as an important regulator of Schwann cell function during development and regeneration. In particular, axonal contact appears to be the primary determinant in induction of the myelinating Schwann cell

\footnotetext{
Received May 23, 1991; revised July 29, 1991; accepted July 31, 1991.

We are grateful to Pam Glenfield for technical assistance, Sue Crewther for veterinary assistance, John Single for his line drawing, and Ingrid Rudolph for secretarial assistance. We thank Drs. Peter Dunkley and Bruce Trapp for reviewing the manuscript. This work was supported by grants from the National Multiple Sclerosis Society of Australia and the Ramaciotti Foundation.

Correspondence should be addressed to Dr. J. W. Heath, The Neuroscience Group, Medical Sciences Building (Room 508), Faculty of Medicine, The University of Newcastle, New South Wales, 2308, Australia.

- Present address: Department of Neurology, Neuromuscular Division, Johns Hopkins University School of Medicine, Baltimore, MD 21205

Copyright (c) 1991 Society for Neuroscience 0270-6474/91/114003-12\$05.00/0
}

phenotype (Weinberg and Spencer, 1975, 1976; Aguayo et al., 1976), which is characterized by synthesis of myelin components such as $\mathrm{P}_{0}, \mathrm{P}_{2}, \mathrm{MBP}$, and galactocerebroside (Mirsky et al., 1980; Politis et al., 1982; Winter et al., 1982; Eccleston et al., 1987; Ranscht et al., 1987) and their assembly into myelin membranes. Conversely, loss of the axon from myelinated fibers following surgical or neurotoxic lesions results in rapid myelin lysis (Asbury, 1975; Allt, 1976). The Schwann cell resumes a less differentiated, nonmyelinated phenotype in which the synthesis of myelin and basal lamina components (Mirsky et al., 1980; Spencer et al., 1981; Politis et al., 1982; Winter et al., 1982; Poduslo et al., 1984, 1985; R. P. Bunge et al., 1986; Trapp et al., 1988; M. B. Bunge et al., 1990; LeBlanc and Poduslo, 1990; Rutkowski et al., 1990; Yao et al., 1990) are downregulated, while molecules such as N-CAM, L1, and Ran-1 (Martini and Schachner, 1986; Jessen et al., 1987) reappear on the Schwann cell surface. These observations have been interpreted to indicate that continued axonal contact is also an absolute requirement for myelin maintenance by Schwann cells. However, recent studies of "double myelination" (Heath, 1982, 1983; Kidd and Heath, 1988a,b) have shown that myelin sheath integrity can be retained in vivo in Schwann cells that have completely lost physical contact with an axon.

Double myelination is present in adult sympathetic nerve (Heath, 1982, 1983; Kidd and Heath, 1988a) and results from displacement of a myelinating Schwann cell from axonal contact due to invasion of another Schwann cell at a node or heminode. Myelin formation by the invading (now "inner") Schwann cell results in the characteristic double ensheathment, because the integrity of the original (now "outer") myelin internode is retained even when it is completely displaced from axonal contact (Heath, 1982; Kidd and Heath, 1988a,b). In addition, the outer sheath undergoes a conformational reorganization involving infolding of the paranodes and the formation of new compact lamellae, events that imply a continuing capability for the synthesis and ordered translocation of myelin components by these displaced Schwann cells. Further support is provided by the rapid incorporation of ${ }^{3} \mathrm{H}$-choline and ${ }^{3} \mathrm{H}$-fucose into the outer shcath (J. W. Hcath and R. M. Gould, unpublished observations) and by the immunocytochemical localization of $P_{0}$ and myelin-associated glycoprotein within the outer sheath/Schwann cell (Heath and Trapp, 1990).

These data suggest that unlike the initial formation of the myelin sheath, axonal contact is not essential for myelin maintenance by Schwann cells. This raises two novel hypotheses: either myelin maintenance is mediated by diffusible trophic factors of axonal origin, or the axon is no longer essential for myelin maintenance. To test these hypotheses, we have established and applied a surgical method of producing degeneration 


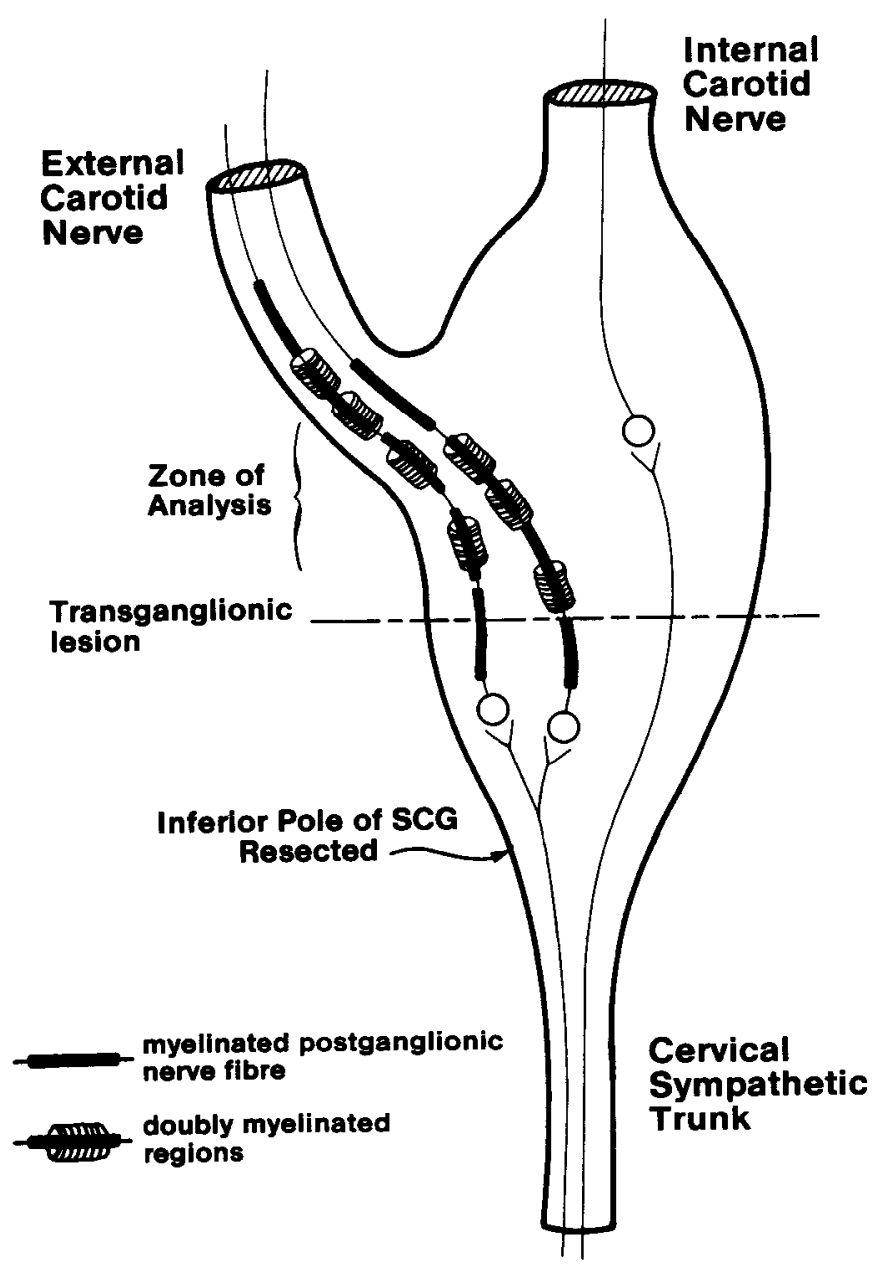

Figure 1. Schematic diagram of the SCG and its major branches. Postganglionic axons projecting into the external carotid nerve from nerve cell bodies in the inferior pole of the SCG (Bowers and Zigmond, 1979) are often myelinated close to the cell soma and may become intermittently doubly myelinated. Few myelinated fibers are found in the internal carotid nerve. Transganglionic lesion (broken line) therefore severed many doubly myelinated axons, and analysis was subsequently performed in the zone $1 \mathrm{~mm}$ superior to the lesion plane. Axons arising from nerve cell bodies above the plane of the lesion would be expected to remain intact provided the vasculature was not compromised. $\mathrm{Re}-$ section of the inferior polc of the SCG together with $5-10 \mathrm{~mm}$ of the preganglionic cervical sympathetic trunk was undertaken to limit axonal regeneration.

of the axons involved in double myelination in the superior cervical ganglion (SCG) of the mouse. We report here that myelin internodes that are completely displaced survive degeneration of the centrally enclosed axon.

A preliminary account of this work has been presented previously (Kidd et al., 1990).

\section{Materials and Methods}

\section{Animal groups, treatment, and tissue preparation}

Fifteen male Q/S mice aged 12-14 months were used, since myelination in the SCG occurs mostly during adult life (Heath, 1983). Animals were anesthetized by intraperitoneal injection of diazepam $(5 \mathrm{mg} / \mathrm{kg})$ followed by fentonyl-droperidol $(0.3 \mathrm{ml} / \mathrm{kg}$; Innovar-Vet, Janssen, Australia; see Green, 1982). The majority of myelinated fibers in the SCG are postganglionic and exit the ganglion via the external carotid nerve (Kidd and Heath, 1988a,b); these fibers arise from nerve cell bodies located in the inferior pole of the ganglion (Bowers and Zigmond, 1979). There- fore, to produce degeneration of the axons involved in double myelination, a surgical lesion was made transversely through the entire body of the right SCG about $1 \mathrm{~mm}$ inferior to the origin of the external carotid nerve (Fig. 1). In a pilot study, axonal regeneration into the superior pole was both widespread and rapid. Therefore, to limit the potential for axonal regeneration in the present study, the inferior pole of the ganglion and approximately $5 \mathrm{~mm}$ of the cervical sympathetic trunk were resected.

Wallerian degeneration of the small-diameter B-fibers of sympathetic nerve occurs rapidly (Dyck and Hopkins, 1972). Two groups of five mice each were killed $1 \mathrm{~d}$ and $5 \mathrm{~d}$ postoperatively, and a third group was examined at 5 weeks to investigate longer-term responses. Under deep Nembutal anesthesia, animals were perfused systemically with $1 \%$ sodium nitrite containing heparin followed by $2.5 \%$ glutaraldehyde and $1 \%$ formaldehyde in $0.1 \mathrm{M}$ sodium cacodylate buffer (Kidd et al., 1986). The remaining supcrior polc of the right SCG and the intact left SCG were dissected out complete with internal and external carotid nerves and cervical sympathetic trunk (left side only), postfixed in buffered osmium tetroxide, and then dehydrated and embedded in TAAB Embedding Resin for light microscopic (LM) and electron microscopic(EM) analysis.

Serial sectioning and tissue analysis. LM and EM analyses of operated (right) and control (left) ganglia were made from sections generated at a standard level, approximately $1 \mathrm{~mm}$ superior to the plane of surgical transection in order to avoid nonspecific tissue damage (see Fig. 1). Serial sectioning was carried out as previously described (Kidd and Heath, 1988a,b). Briefly, serial sections were generated as repeating sequences consisting of one thick section (approximately $0.5 \mu \mathrm{m}$ ) followed immediately by $6-8$ thin sections (silver-gray interference colors; approximatcly $70 \mathrm{~nm}$ ). A typical scquence of sections consisted of about 60 thick/thin sequences, representing approximately $60 \mu \mathrm{m}$ in tissue depth. Blocks were orientated such that most myelinated fibers were in longitudinal section. Thick sections were stained with toluidine blue plus basic fuchsin (Electron Microscope Sciences). Thin sections were mounted on uncoated high-transmission hexagonal grids (Gilder grids), double stained with uranyl acetate and lead citrate, carbon coated, and examined in a JEOL $100 \mathrm{CX}$ transmission electron microscope.

\section{Results}

Nerve fiber degeneration after transganglionic lesion

The effect of complete transection of the body of the SCG has not been reported previously. This was important to investigate first in order to establish whether or not widespread nonspecific effects might result, perhaps due to compromised blood supply. As expected, at the lesion site nonspecific traumatic damage was evident at $1 \mathrm{~d}$ postoperatively. Most blood vessels were occluded by platelets and erythrocytes even following perfusion fixation, and there was widespread disruption within nerve cell bodies and supporting cells. In myelinated fibers, major myelin disruption (loosening of lamellar membranes; see Weller and Cervós-Navarro, 1977) occurred simultaneously with the initial stages of axonal degeneration and was sometimes evident even in the absence of detectable axonal damage.

In contrast, within the zone of analysis $(1 \mathrm{~mm}$ above the lesion; see Fig. 1), the blood vessels were consistently well perfused and free from erythrocytes and platelet aggregation (Fig. 2). Monocytes gained access to the surrounding tissue via the vessel walls, indicating competent traffic of hematogenous cells. In this zone, nerve cell bodies, satellite cells, and some myelinated and unmyelinated fibers (see below) remained ultrastructurally intact at all postoperative stages. Degenerating myelinated fibers followed the classical Wallerian pattern of degeneration in which initial disruption of the axon (Fig. 3) was followed by splitting of individual myelin lamellae and the appearance of lipid droplets and myelin debris within the Schwann cell cytoplasm (Fig. 4). By $5 \mathrm{~d}$, the majority of disrupted sheaths appeared as loosened myelin membranes engulfed by hematogenous phagocytes or Schwann cells. Numerous bands of Büngner, 


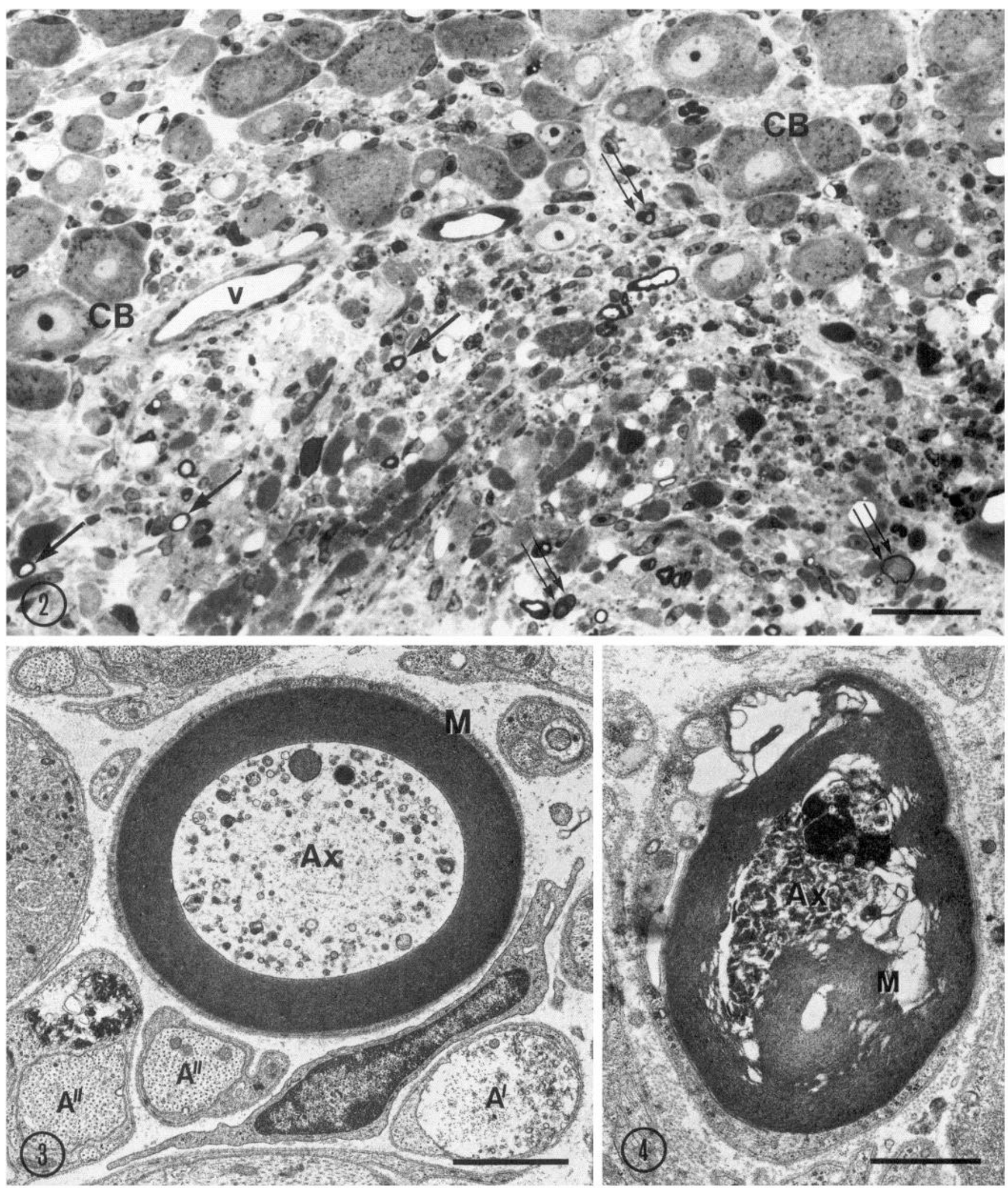

Figure 2. LM appearance of an area of the zone of analysis $1 \mathrm{~d}$ postoperatively. Small blood vessels $(v)$ are well perfused. Nerve cell bodies $(C B)$ and some myelinated fibers appear intact (single arrows), though other fibers appear damaged (double arrows). Scale bar, $50 \mu \mathrm{m}$.

Figure 3. Initial degeneration (1 d postoperatively) involved intra-axonal $(A x, A)$ accumulation of debris and organelles and cytoskeletal disruption. In contrast, some adjacent axons $\left(A^{\prime \prime}\right)$ remain intact, apparently uninvolved by the transection. The myelin sheath $(M)$ appears little affected at this stage. Scale bar, $2 \mu \mathrm{m}$.

Figure 4. Advanced degeneration ( $5 \mathrm{~d}$ postoperatively). Remnants of the axon $(A x)$ are surrounded by a highly disrupted myelin sheath $(M)$. Scale bar, $1 \mu \mathrm{m}$. 

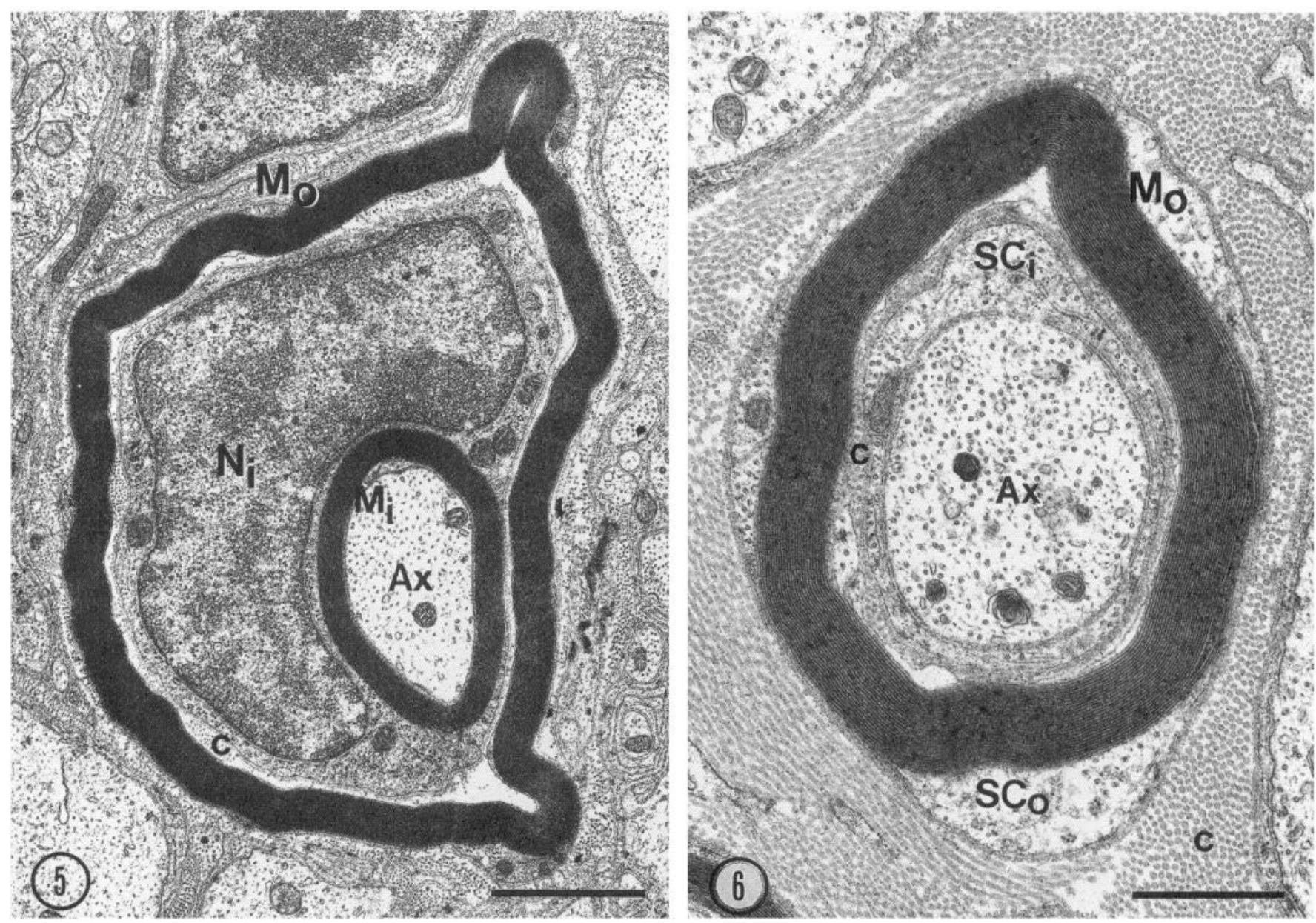

Figure 5. A doubly myelinated fiber from control tissue in transverse section. The central axon $(A x)$ is ensheathed in the usual intimate fashion by an inner Schwann cell (nucleus, $N_{i}$ ) and myelin sheath $\left(M_{i}\right)$. This region of the fiber is further surrounded by a second (outer) myelin sheath $\left(M_{o}\right)$ produced by another Schwann cell. $c$, collagen fibrils. Scale bar, $1.5 \mu \mathrm{m}$.

Figure 6. An outer myelin sheath $\left(M_{o}\right)$ and Schwann cell $\left(S C_{o}\right)$ from control SCG, in which the central axon $(A x)$ is surrounded by a nonmyelinating inner Schwann cell $\left(S C_{i}\right)$. Subsequent myelin formation by the inner cell results in the characteristic double ensheathment (Kidd and Heath, 1988b). $c$, collagen fibrils. Scale bar, $1 \mu \mathrm{m}$.

comprising Schwann cells and their reorganized cytoplasmic processes surrounded by a basal lamina, were present both $5 \mathrm{~d}$ and 5 weeks postoperatively.

The proportion of myelinated axons lesioned by this technique (i.e., undergoing degeneration at $1 \mathrm{~d}$ postoperatively) varied among animals from about $25 \%$ to $95 \%$. Though we did not attempt a quantitative comparison, the resection procedure adopted in this study substantially reduced axonal regeneration compared with that found in nonresected animals. Axonal sprouting was observed only rarely within the zone of analysis.

\section{Double myelination in control ganglia}

The following description is limited to features relevant to interpretation of the effects of the surgical lesion (see below). By EM examination, double myelination typically comprised an axon and inner myelinating Schwann cell, enclosed by an outer, displaced myelin internode (Fig. 5). Formative stages of double myelination were also present, where displacement of the original internode was incomplete or where the displacing Schwann cell had not yet commenced myelin formation (Fig. 6; see Kidd and Heath, 1988a,b, for details).

\section{Response of outer internodes following transection}

The primary degenerative response in doubly myelinated fibers $1 \mathrm{~d}$ postoperatively involved the accumulation of cellular debris and dense bodies in the axoplasm and disruption of the axonal cytoskeleton (Fig. 7), as in singly ensheathed fibers. At this early stage, the inner and outer myelin sheaths were largely intact structurally, although small cytoplasmic lipid droplets sometimes heralded degenerative changes in inner Schwann cells, and in those outer cells that still retained some axonal contact (Fig. $7 C, E$ ). In configurations at more advanced stages of degeneration ( 1 and $5 \mathrm{~d}$ ), inner sheath degeneration progressed from focal splitting of lamellae to extensive loosening of myelin membranes and phagocytosis of debris (see Figs. $8 B, 10$ ), as in singly myelinated fibers.

Regarding the outer internodes, two distinct outcomes were evident. In many configurations the outer sheath broke down at the same time and in the same manner as the inner sheath (not shown). In these cases, the inner and outer sheaths were usually too disrupted to determine the relationship between the axon and outer sheath in serial sections, but in the few profiles 


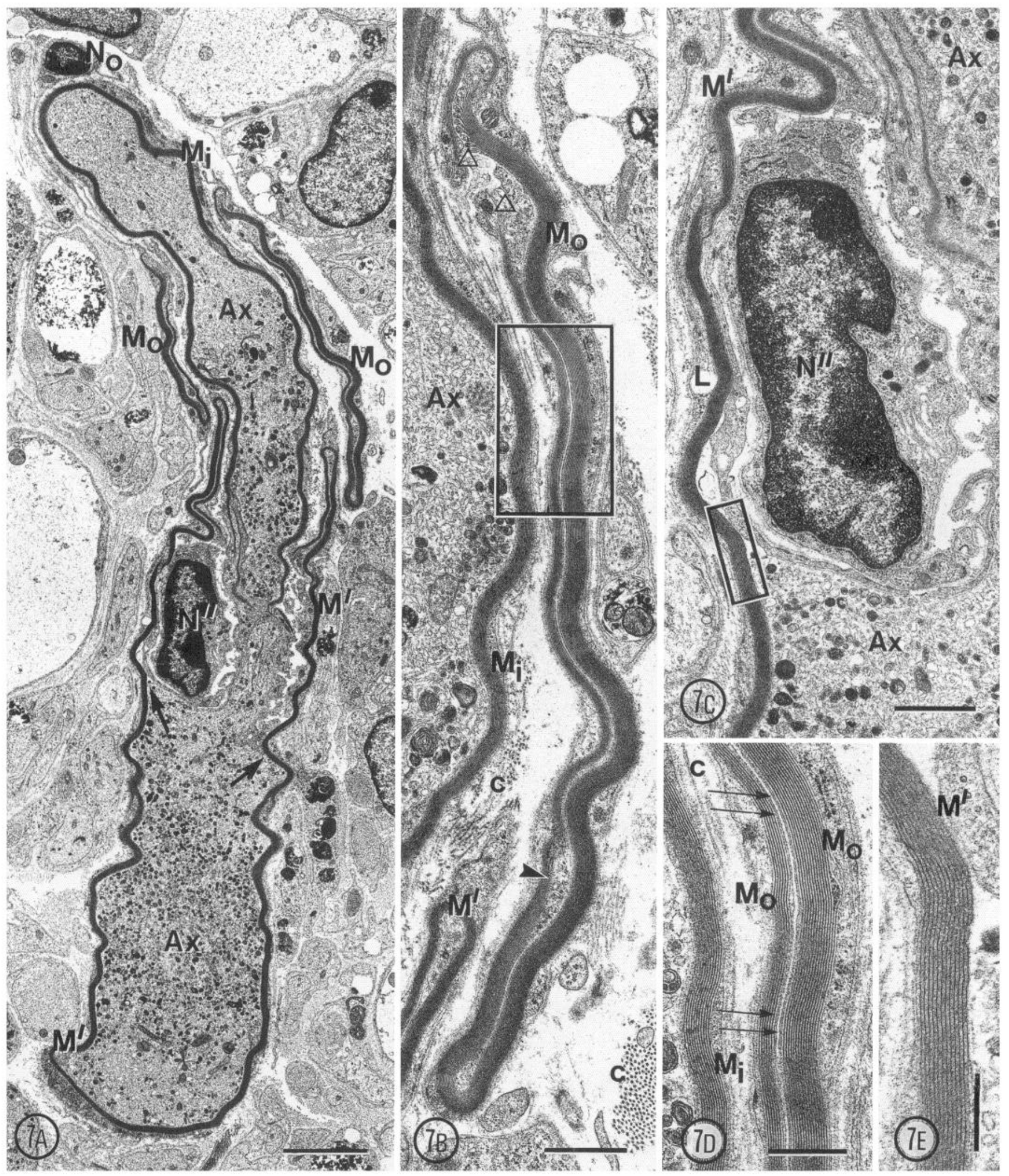

Figure 7. A, Axonal degeneration within a doubly myelinated fiber $1 \mathrm{~d}$ postoperatively. The outer sheath $\left(M_{o}\right)$ and Schwann cell (nucleus, $\left.N_{o}\right)$ are displaced from the degenerating axon $(A x)$ and inner sheath $\left(M_{i}\right)$. The lower internode $(M)$ is also partly detached from the axon (above arrows). $N^{\prime \prime}$, nucleus of supernumerary Schwann cell. $B$ and $D$, At higher magnification, both inner $\left(M_{i}\right)$ and outer sheaths $\left(M_{o}\right)$ appear ultrastructurally intact (boxed region in $B$ is shown at higher magnification in $D$ ). Extensive infolding (triangles in $B$ indicate paranodal pockets), producing juxtaposition of "adaxonal" plasma membranes (double arrows, $D$ ), and myelin attenuation (arrowhead, $B$ ) are typical features of double myelination in normal animals. $c$, collagen fibrils. $C$ and $E$, Ultrastructure of the lower, partly displaced internode $(M)$ also appears intact at this stage, though cytoplasmic lipid droplets $(L)$ are present (boxed region in $C$ is shown at higher magnification in $E$ ). $N^{\prime \prime}$, nucleus of supernumerary Schwann cell. Scale bars: $A, 3.5 \mu \mathrm{m} ; B, 1.25 \mu \mathrm{m} ; C, 1 \mu \mathrm{m} ; D, 0.5 \mu \mathrm{m} ; E, 0.3 \mu \mathrm{m}$. 

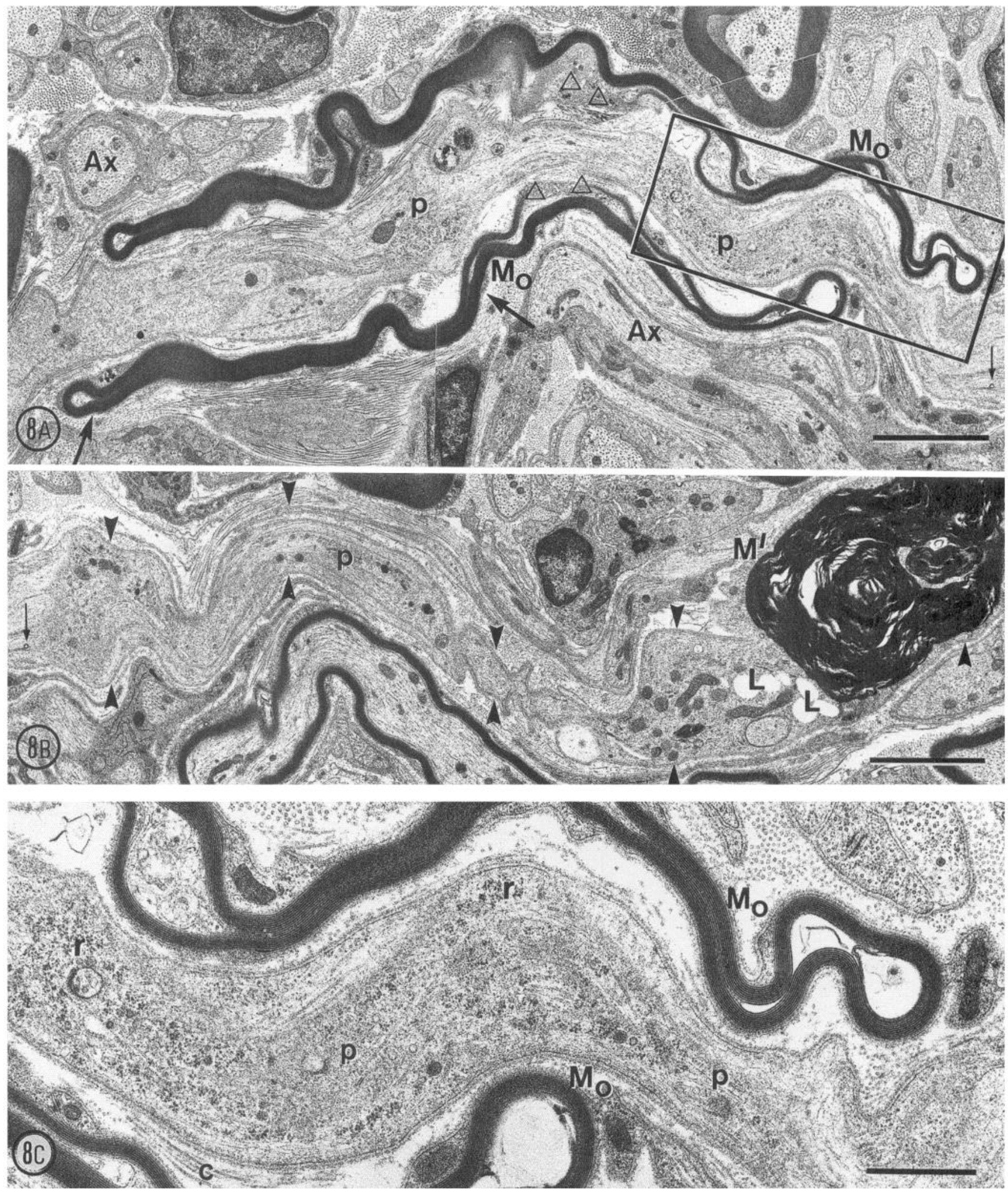

Figure 8. $A$ and $B$, Montage of a surviving outer sheath $\left(M_{o}\right)$ in longitudinal section $5 \mathrm{~d}$ postoperatively. The extent of overlap of $A$ and $B$ is indicated on each by the small vertical arrow. This sheath surrounds numerous reorganized cytoplasmic processes $(p)$ within a basal lamina. No evidence of the former axon remains, though myelin debris $\left(M^{\prime}\right.$ in $\left.B\right)$ within the same continuous inner basal lamina (arrowheads) probably represents the residuum of the inner sheath. The outer myelin internode appears intact, including characteristic features such as complete infolding (triangles indicate "paranodal" regions) and new compaction of infolded membranes to form regions of greater myelin thickness $(A$, between angled arrows). $L$, lipid droplet; $A x$, axon. $C$, Higher magnification from boxed region in $A$. Ribosomes $(r)$ in the inner processes $(p)$ distinguish them from nearby axons (refer to $A$ ). $c$, collagen fibrils. Scale bars: $A$ and $B, 2.5 \mu \mathrm{m} ; C, 1 \mu \mathrm{m}$. 

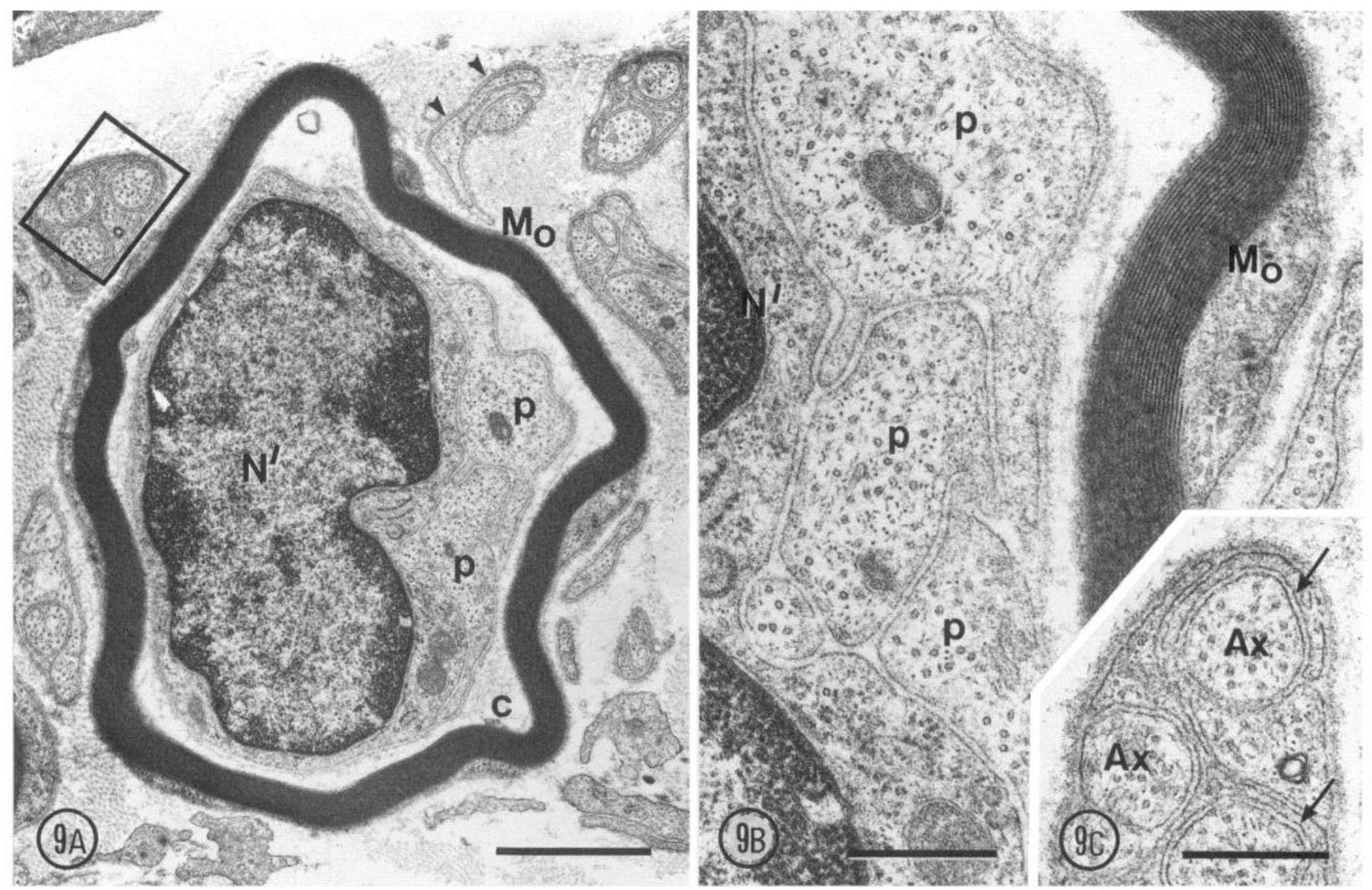

Figure 9. A, A surviving outer sheath $\left(M_{o}\right)$ in transverse section $5 \mathrm{~d}$ postoperatively. This sheath and Schwann cell surround an inner Schwann cell (nucleus, $N$ ) and several cytoplasmic processes $(p)$, similar in arrangement to nearby stacks of Schwann cell processes (arrowheads). $c$, collagen fibrils. $B$, Higher-magnification view of section in $A$. The irregular profile and arrangement of these processes $(p)$ contrasts with nearby unmyelinated axons $\left(C\right.$, same magnification). Where the plane of section is appropriate, the lamellar structure of the outer sheath $\left(M_{o}\right)$ is intact. $C$, Higher magnification from boxed region in $A$. Adjacent unmyelinated axons $(A x)$ are directly ensheathed by Schwann cell plasma membrane (arrows) and are circular in profile. Scale bars: $A, 1.5 \mu \mathrm{m} ; B$ and $C, 0.5 \mu \mathrm{m}$.

where analysis was possible the degenerating outer sheaths retained axonal contact. We never observed breakdown of an outer sheath that was completely displaced from the degenerating central axon.

In contrast, in the remaining group of 20 outer internodes, the ordered lamellar structure of the myelin sheath was consistently retained irrespective of the degenerative state of the axon and inner sheath. The outer Schwann cell maintained a close association with its sheath, and cytoplasmic lipid droplets were not detected (Figs. 8-12). In addition, surviving outer sheaths retained other features typical of outer sheaths in control tissue, including extensive infolding of the "paranodes" and new compaction of the apposing Schwann cell plasma membranes within these infolded regions (Fig. 8; see Kidd and Heath, 1988a, for detailed description of these events in control tissue). At 5 weeks postoperatively, surviving internodes were found in all animals.

Within surviving outer internodes, bands of Büngner formed as a result of reorganization of cytoplasmic processes and mitosis of the inner Schwann cells (Figs. 8; 9A,B; 11; 12A,B). These bands of Büngner were thus directly enclosed by the residual basal lamina of the inner Schwann cells and were separated from the outer internode by endoneurial space containing numerous small-diameter $(<20 \mathrm{~nm})$ collagen fibrils (Figs. $8 C ; 9 A ; 11$; $12 A, B)$. Schwann cells of the band of Büngner sometimes con- tained myelin debris (Figs. $8 B, 10$ ), presumably remnants of the inner sheath. In addition, debris-laden hematogenous phagocytes were frequently found within the surviving internodes (Fig. 11 ), indicating that these cells also were active in scavenging and processing myelin from the inner sheath. However, primary phagocytic attack on the completely displaced, morphologically intact outer myelin sheath by these hematogenous cells was not observed, even though these cells were often in close proximity to the "adaxonal" surface of the outer Schwann cell (Fig. 11). By 5 weeks, most of the degenerating myelin had been digested or transported from the ganglion by hematogenous phagocytes.

\section{Axonal regeneration within surviving outer internodes}

In doubly myelinated fibers in control tissue, without exception there is only a single central axon, which is fully ensheathed by the inner Schwann cell (Figs. 5, 6). In the present study, these two characteristic features permitted axonal regeneration within surviving outer internodes to be distinguished from doubly myelinated configurations in which the axon remained intact, due presumably to its origin from a nerve cell body positioned above the lesion plane (Fig. 1). Having resected the inferior pole of the SCG, axonal regeneration within surviving outer internodes was rare (Figs. 13 and 14 illustrate the only two examples found) and was identified by incomplete Schwann cell investment by 

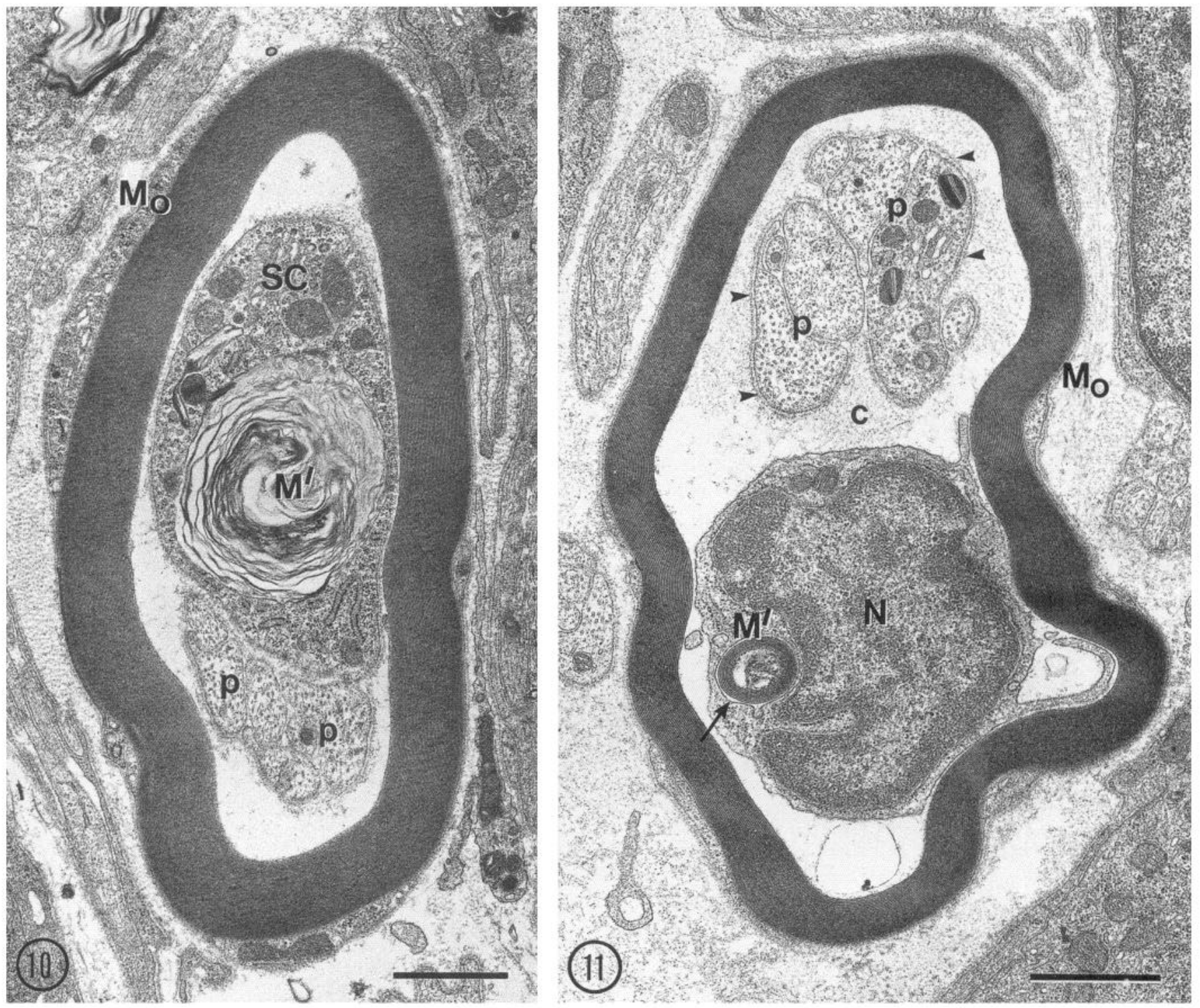

Figure 10. A surviving outer sheath $\left(M_{o}\right)$ and Schwann cell in transverse section ( $5 \mathrm{~d}$ postoperatively) surround several cytoplasmic processes (p), and also a region of Schwann cell cytoplasm $(S C)$ containing a whorl of loosened myelin $(M)$, which may be a remnant of the inner sheath. Scale bar, $1.5 \mu \mathrm{m}$.

Figure 11. A surviving outer sheath $\left(M_{o}\right)$ and Schwann cell $5 \mathrm{~d}$ postoperatively. In this case, the outer sheath encloses a hematogenous cell (nucleus, $N$ ), which contains a small region of degenerating myelin $(M)$ within a membrane-limited phagosome (arrow). While exploratory processes extend along the "adaxonal" surface of the surviving sheath, phagocytosis of that sheath has not occurred. Cytoplasmic processes $(p)$ are surrounded by a basal lamina (arrowheads) and numerous collagen fibrils (c). Scale bar, $1.3 \mu \mathrm{m}$.

the inner Schwann cell (Fig. 13) and/or the presence of multiple central axons (Fig. 14). Even where partially ensheathed, the plasma membrane of regenerating axons and their investing Schwann cells were closely apposed (Fig. 13; see also Fig. 9C), and prominent mesaxons developed as ensheathment proceeded (Fig. 14). In contrast, regenerating sprouts were absent from the great majority of surviving internodes, and the Schwann cell processes of the inner band of Büngner simply abutted one another (Figs. 9-12). In addition, axons were relatively electron lucent and circular in profile and lacked ribosomes and rough endoplasmic reticulum (Figs. 13,14), while Schwann cell processes of the band of Büngner contained free ribosomes, rough endoplasmic reticulum (Fig. $8 C$ ), and intermediate filaments (Figs. 9B, 11, 12B).

\section{Discussion}

While the SCG is a frequently used experimental tissue, the transganglionic lesion required in this study has not been reported previously. Therefore, before considering the response of doubly myelinated fibers, it was necessary to establish that the surgical procedure did not produce nonspecific trauma or ischemia due to interruption of the blood supply that arises from the adjacent carotid vessels. At all postoperative stages, the perfusion fixation method cleared virtually all blood cells from the zone of analysis, and hematogenous cells gained access to the tissue via the vessel walls, indicating a competent vascular supply. Nerve cell bodies in the zone of analysis remained intact. Some intact myelinated and unmyelinated fibers were always 


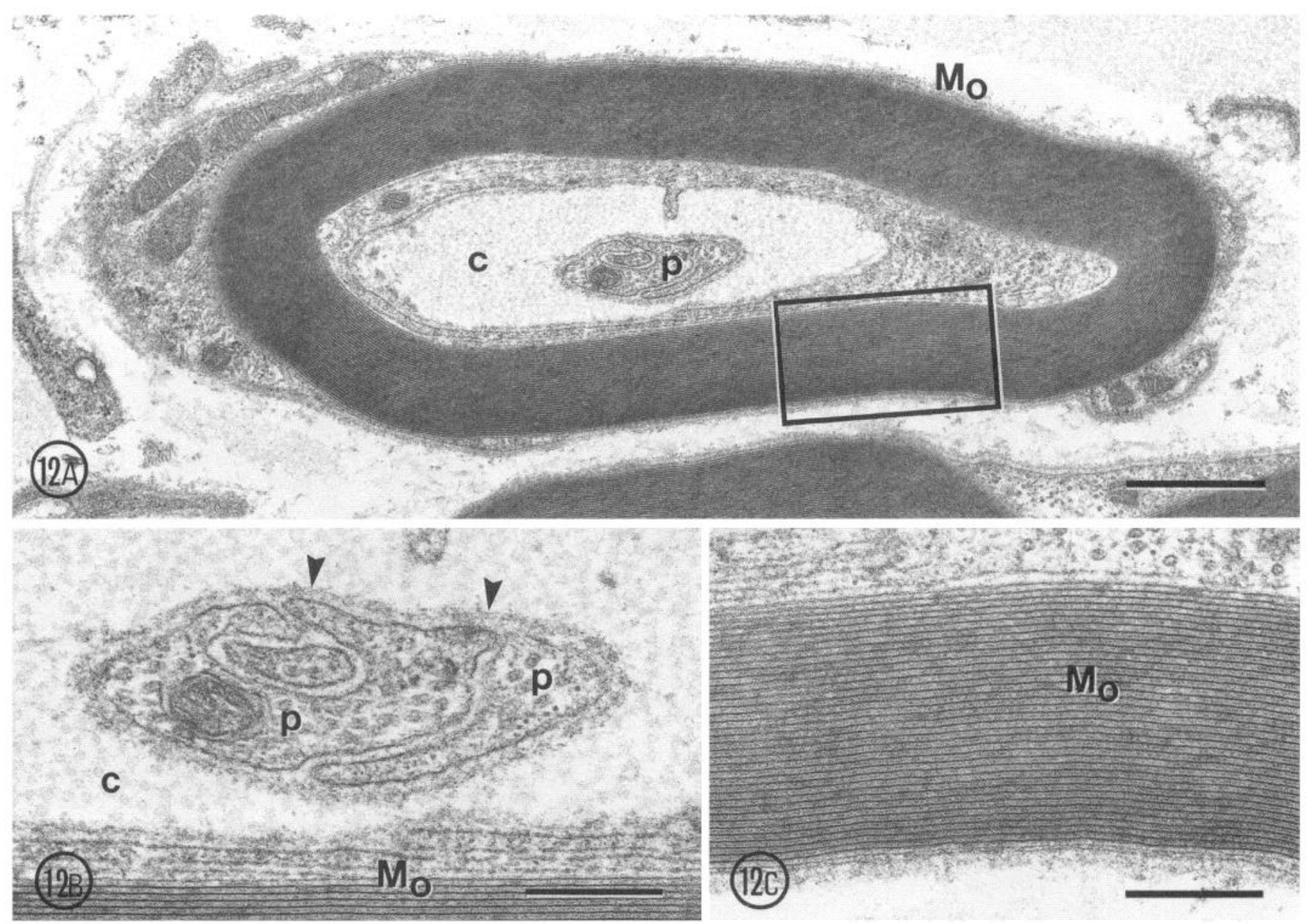

Figure 12. A, A surviving outer sheath $\left(M_{o}\right), 5$ weeks postoperatively, encircles a small number of cytoplasmic processes $(p)$ and collagen fibrils (c). $B$, Higher magnification of the cytoplasmic processes $(p)$, which are surrounded by a basal lamina (arrowheads) and a matrix of collagen fibrils (c). $C$, Higher-magnification view of boxed region in $A$. Where the plane of section is appropriate, the ordered lamellar structure of the outer sheath $\left(M_{o}\right)$ is evident. Scale bars: $A, 1 \mu \mathrm{m} ; B$ and $C, 0.4 \mu \mathrm{m}$.

found and are likely to arise from cell bodies located superior to the lesion plane (Bowers and Zigmond, 1979). Finally, where present, myelin breakdown was secondary to axonal degeneration, typical of Wallerian degeneration. We were therefore confident that responses observed in doubly myelinated fibers represented a specific effect of transecting the centrally enclosed axon.

Schwann cell production of myelin components is substantially downregulated following nerve transection or dissociation from the axon under tissue culture conditions (Mirsky et al., 1980; Spencer et al., 1981; Politis et al., 1982; Winter et al., 1982; Poduslo et al., 1984, 1985; Eccleston et al., 1987; Trapp et al., 1988; LeBlanc and Poduslo, 1990; Rutkowski et al., 1990; Yao et al., 1990). These data have been interpreted generally to indicate a continuing requirement for the axon in myelin maintenance. However, studies of double myelination in normal adult sympathetic nerve have demonstrated that myelin integrity is retained in Schwann cells that lack physical contact with an axon (Heath, 1982, 1983; Kidd and Heath, 1988a,b). The major finding of this study is that myelin internodes that are completely displaced from axonal contact survive surgically induced degeneration of the centrally enclosed axon. We conclude that axonal factors are not required for myelin maintenance in the SCG.

Concerning outer myelin internodes, two distinct outcomes were noted following surgery. Where the outer Schwann cell was completely displaced from the degenerating axon, integrity of the outer sheath was retained regardless of the degenerative state of the inner sheath and axon. Surviving outer internodes displayed intact lamellar organization, infolding of the "paranodes," and new myelin compaction within infolded regions, features that require the synthesis and ordered intercalation of myelin components into the sheath (see Kidd and Heath, 1988a, for details of these events in control tissue). When it occurred in this tissue, myelin degeneration was rapid, yet outer internodes survived for 5 weeks postoperatively (the longest time point in this study), and more recent work has demonstrated survival for 16 weeks (G. J. Little, personal communication). In contrast, in other configurations the outer myelin sheath broke down at the same time as the inner sheath and axon. Serial sectioning of these profiles at early stages of degeneration indicated that the outer Schwann cell still retained some degree of axonal contact (as shown in Fig. 7). Consistent with this view, degenerating outer sheaths were found only at 1 and $5 \mathrm{~d}$ post- 


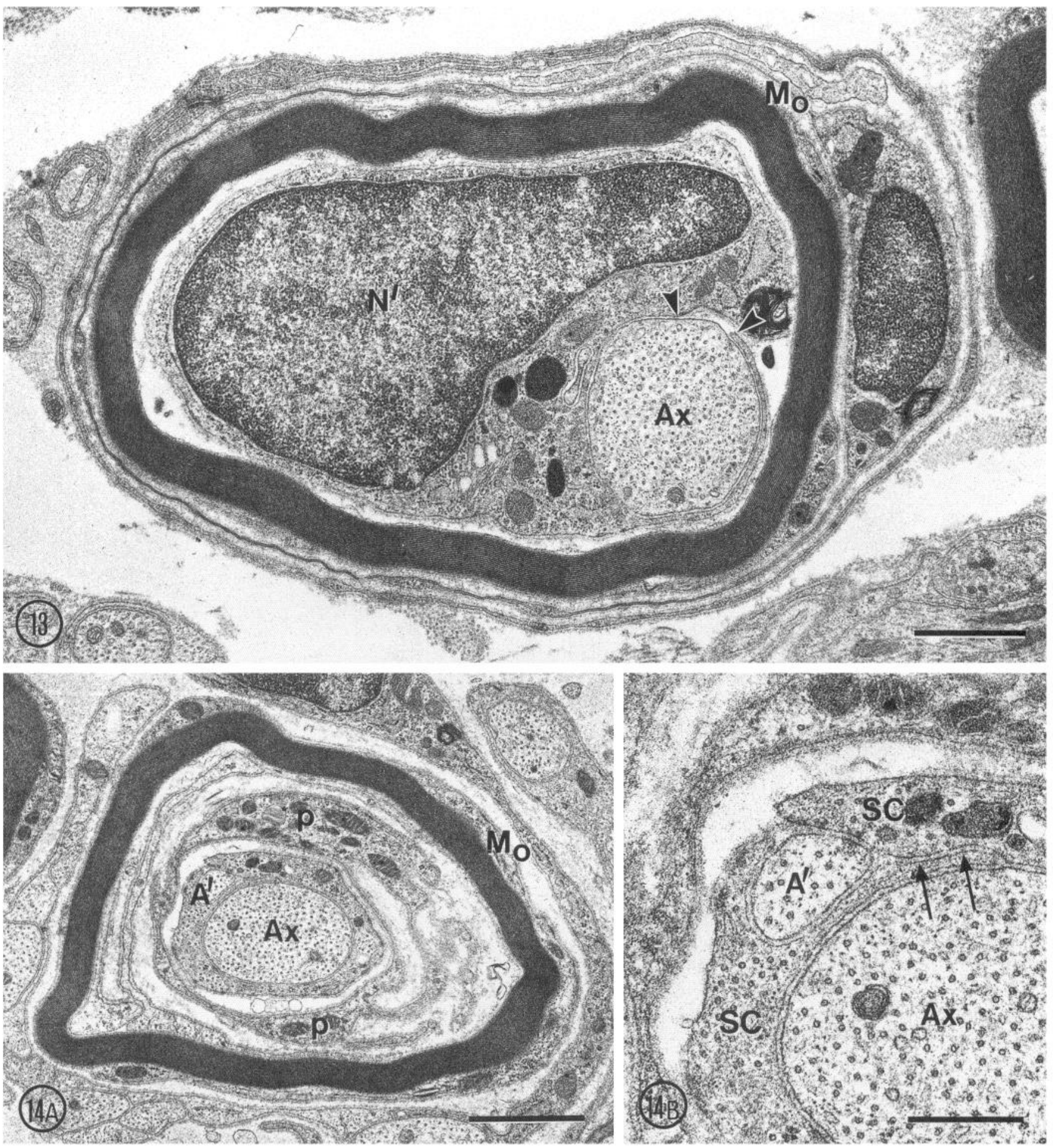

Figure 13. Axonal regeneration within a surviving outer sheath $\left(M_{o}\right)$ and Schwann cell, $5 \mathrm{~d}$ postoperatively. The axon $(A x)$ is ensheathed by an inner Schwann cell (nucleus, $N$ ). However, this investment is incomplete (between arrowheads), in contrast to that of doubly myelinated fibers in control tissue (compares Figs. 5, 6). Scale bar, $1.25 \mu \mathrm{m}$.

Figure 14. A, Axonal regeneration within a surviving sheath $\left(M_{o}\right), 5 \mathrm{~d}$ postoperatively. In addition to extensive cytoplasmic processes ( $p$ ), two axons ( $A x$ and $A)$ are enclosed (compare Figs. 5, 6). B. Higher magnification from $A$. Both axons are directly ensheathed by Schwann cell (SC) plasma membrane, creating a mesaxon (arrows). Scale bars: $A, 1.75 \mu \mathrm{m} ; B, 0.5 \mu \mathrm{m}$.

operatively, that is, during the period of rapid axonal degeneration characteristic of sympathetic nerve (Dyck and Hopkins, 1972).

Resection of the inferior pole of the SCG was effective in minimizing axonal regeneration in this tissue and was undertaken because regenerating axonal sprouts were perceived as a potential source of trophic factors that may have influenced outer sheath maintenance. Regenerating axons were found only 
rarely within surviving outer internodes at 1 and $5 \mathrm{~d}$ postoperatively, based on morphological criteria combined with serial sectioning. In addition, where present, regenerating sprouts were ensheathed by Schwann cells of the inner band of Büngner in typical Remak manner, including the development of prominent mesaxons. This pattern contrasted with the stacking of Schwann cell processes in profiles lacking regenerating axons. Therefore, we consider it unlikely that regenerating axons were responsible for the survival of outer internodes. In a complementary study (Kidd et al., 1991), we have used the drug guanethidine to achieve a chemical sympathectomy in rats and again demonstrated survival of outer internodes in the absence of axons/axonal regeneration. Guanethidine produces selective degeneration of the entire sympathetic postganglionic neuron (Burnstock et al., 1971; Heath et al., 1972; Johnson and Manning, 1984; Kidd et al., 1986), thus minimizing the potential for axonal regeneration long term.

Interactions between Schwann cells and macrophages have been implicated in the events of Wallerian degeneration (Beuche and Friede, 1984; Stoll and Müller, 1986; Lindholm et al., 1987; Perry et al., 1987; Stoll et al., 1989). In particular, studies of C57BL/Ola mice (Lunn et al., 1989; Perry et al., 1990) have suggested that recruitment of macrophages into transected peripheral nerve plays a critical role in initiating Wallerian degeneration. In the transected SCG macrophages were numerous and participated in the rapid degeneration of single and partially displaced myelin sheaths, indicating that outer sheath survival was not due to inadequate recruitment or phagocytic capability of macrophages. Furthermore, debris-containing macrophages were often found closely adjacent to surviving other sheaths, demonstrating that absence of axonal contact combined with close proximity to activated macrophages was alone not sufficient to initiate myelin breakdown.

In Wallerian degeneration, the mechanisms that initiate the secondary responses of Schwann cells such as myelin breakdown and mitosis have not been established (Bigbee et al., 1987; Oaklander et al., 1987; White et al., 1989; LoPachin et al., 1990), but could involve the loss of axonal contact and of trophic substances normally supplied by the axon (Joseph, 1973; Oaklander and Spencer, 1988). Alternatively, in Wallerian degeneration the Schwann cell is exposed also to axonal debris, lytic enzymes, and potentially a range of molecules that may act as signal factors that specifically initiate a destructive response in Schwann cells (Joseph, 1973; Lubinska and Jastreboff, 1977). In double myelination, completely displaced myelin internodes are maintained long term in normal animals (Heath, 1982; Kidd and Heath, 1988a) and survive degeneration of the axon and inner sheath (Kidd et al., 1991; present results). These data support the view that myelin breakdown in Wallerian degeneration is initiated by a positive signal, originating from the degenerating axon. In the case of double myelination, it appears that this putative signal requires axonal contact since inner internodes and partially displaced internodes broke down following axonal degeneration, while completely displaced internodes remained intact.

\section{References}

Aguayo AJ, Epps J, Charron L, Bray GM (1976) Multipotentiality of Schwann cells in cross anastamosed and grafted myelinated and unmyelinated nerves: quantitative microscopy and autoradiography. Brain Res 104:1-20.
Allt G (1976) Pathology of the peripheral nerve. In: The peripheral nerve (Landon DN, ed), pp 1-105. London: Chapman and Hall.

Asbury AK (1975) The biology of Schwann cells. In: Peripheral neuropathy, Vol 1 (Dyck PJ, Thomas PK, Lambert EH, eds), pp 210212. Philadelphia: Saunders.

Beuche W, Friede RL (1984) The role of non-resident cells in Wallerian degeneration. J Neurocytol 13:767-796.

Bigbee JN, Yoshino JE, De Vries GH (1987) Morphological and proliferative responses of cultured Schwann cells following rapid phagocytosis of a myelin-enriched fraction. J Neurocytol 16:487-496.

Bowers CW, Zigmond RE (1979) Localization of neurons in the rat superior cervical ganglion that project into different postganglionic trunks. J Comp Neurol 186:381-392.

Bunge MB, Clark MB, Dean AC, Eldridge CF, Bunge RP (1990) Schwann cell function depends upon axonal signals and basal lamina components. Ann NY Acad Sci 580:281-287.

Bunge RP, Bunge MB, Eldridge CF (1986) Linkage between axonal ensheathment and basal lamina production by Schwann cells. Annu Rev Neurosci 9:305-328.

Burnstock G, Evans B, Gannon BJ, Heath JW, James V (1971) A new method of destroying adrenergic nerves in adult animals using guanethidine. Br J Pharmacol 43:295-301.

Dyck PJ, Hopkins AP (1972) Electron microscopic observations on degeneration and regeneration of unmyelinated fibres. Brain 95:223234.

Eccleston PA, Mirsky R, Jessen KR, Sommer I, Schachner M (1987) Postnatal development of rat peripheral nerves: an immunohistochemical study of membrane lipids common to non-myelin forming Schwann cells, myelin forming Schwann cells and oligodendrocytes. Dev Brain Res 35:249-256.

Green CJ (1982) Animal anaesthesia. London: Laboratory Animals.

Heath JW (1982) Double myelination of axons in the sympathetic nervous system. J Neurocytol 1 1:249-262.

Heath JW (1983) The sympathetic nervous system: a novel perspective on the control of myelinating Schwann cells. In: Molecular pathology of nerve and muscle (Kidman AD, Tomkins JK, Morris CA, Cooper NA, eds), pp 21-37. Clifton, NJ: Humana.

Heath JW, Trapp BD (1990) Changing immunocytochemical localisation of myelin-associated glycoprotein in myelin internodes displaced from axonal contact. Proc Aust Neurosci Soc 1:84.

Heath JW, Evans BK, Gannon BJ, Burnstock G, James V (1972) Degeneration of adrenergic neurons following guanethidine treatment. An ultrastructural study. Virchows Arch [Cell Pathol] 11:182-197.

Jessen KR, Mirsky R, Morgan L (1987) Myelinated, but not unmyelinated axons, reversibly down-regulate N-CAM in Schwann cells. J Neurocytol 16:681-688.

Johnson EM, Manning PT (1984) Guanethidine induced destruction of sympathetic neurons. Int Rev Neurobiol 25:1-37.

Joseph BS (1973) Somatofugal events in Wallerian degeneration: a conceptual overview. Brain Res 59:1-18.

Kidd GJ, Heath JW (1988a) Double myelination of axons in the sympathetic nervous system of the mouse. I. Ultrastructural features and distribution. J Neurocytol 17:245-261.

Kidd GJ, Heath JW (1988b) Double myelination of axons in the sympathetic nervous system of the mouse. II. Mechanisms of formation. J Neurocytol 17:263-276.

Kidd GJ, Heath JW, Dunkley PR (1986) Degeneration of myelinated sympathetic nerve fibres following treatment with guanethidinc. J Neurocytol 15:561-572.

Kidd GJ, Heath JW, Trapp BD, Little GJ, Dunkley PR (1990) Myelin sheath maintenance in the absence of axons. Ann NY Acad Sci, in press.

Kidd GJ, Heath JW, Trapp BD, Dunkley PR (1991) Myelin sheath survival following guanethidine-induced axonal degeneration. J Cell Biol, in press.

LeBlanc AC, Poduslo JF (1990) Axonal modulation of myelin gene expression in the peripheral nerve. J Neurosci Res 26:317-326.

Lindholm D, Heumann R, Meyer M, Thoenen H (1987) Interleukin-1 regulates synthesis of nerve growth factor in non-neuronal cells of rat sciatic nerve. Nature 330:658-659.

LoPachin RM Jr, LoPachin VR, Sauberman AJ (1990) Effects of axotomy on distribution and concentration of elements in rat sciatic nerve. J Neurochem 54:320-332.

Lubinska L, Jastreboff P (1977) Early course of Wallerian degeneration in myelinated fibres of the rat phrenic nerve. Brain Res 130:47-63. 
Lunn ER, Perry VH, Brown MC, Rosen H, Gordon S (1989) Absence of Wallerian degeneration does not hinder regencration in peripheral nerve. Eur J Neurosci 1:27-33.

Martini R, Schachner M (1986) Immunoelectron microscope localization of neural cell adhesion molecules (L1, N-CAM and MAG) and their shared carbohydrate epitope and myelin basic protein in developing sciatic nerve. J Cell Biol 103:2439-2448.

Mirsky R, Winter J, Abney ER, Pruss RM, Gavrilovic J, Raff MC (1980) Myelin-specific proteins and glycolipids in rat Schwann cells and oligodendrocytes in culture. J Cell Biol 84:483-494.

Oaklander AL, Spencer PS (1988) Cold blockade of axonal transport activates premitotic activity of Schwann cells and Wallerian degeneration. J Neurochem 50:490-496.

Oaklander AL, Miller MS, Spencer PS (1987) Rapid anterograde spread of premitotic activity along degenerating cat sciatic nerve. J Neurochem 48:111-114.

Perry VH, Brown MC, Gordon S (1987) The macrophage response to central and peripheral nerve injury: a possible role for macrophages in regeneration. J Exp Med 165:1218-1223.

Perry VH, Brown MC, Lunn ER, Tree P, Gordon S (1990) Evidence that very slow Wallerian degeneration in C57BL/Ola mice is an in trinsic property of the peripheral nerve. Eur J Neurosci 2:802-808.

Poduslo JF, Berg CT, Dyck PJ (1984) Schwann cell expression of a major myelin glycoprotein in the absence of myelin assembly. Proc Natl Acad Sci USA 81:1864-1866.

Poduslo JF, Dyck PJ, Berg CT (1985) Regulation of myelination: Schwann cell transition from a myelin-maintaining state to a quiescent state after permanent nerve transection. J Neurochem 44:388400.

Politis MJ, Sternberger N, Ederle K, Spencer PS (1982) Studies on the control of myelinogenesis. IV. Neuronal induction of Schwann cell myelin-specific protein synthesis during nerve fiber regeneration. J Neurosci 2:1252-1266.

Ranscht B, Wood PM, Bunge RP (1987) Inhibition of in vitro peripheral myelin formation by monoclonal anti-galactocerebroside. $\mathrm{J}$ Neurosci 7:2936-2947.
Rutkowski L, Needham L, Frayer K, Carson D, McKhann G, Tennekoon G (1990) Evidence that secondary rat Schwann cells in culture maintain their differentiated phenotype. J Neurochem 54:1895-1904.

Spencer PS, Politis MJ, Pellegrino RG, Weinberg HJ (1981) Control of Schwann cell behaviour during nerve degeneration and regeneration. In: Posttraumatic peripheral nerve regeneration: experimental basis and clinical implications (Gorio A, Millesi H, Mingrino S, eds), pp 411-426. New York: Raven.

Stoll G, Müller HW (1986) Macrophages in the peripheral nervous system and astroglia in the central nervous system of rat commonly express apolipoprotein $\mathrm{E}$ during development but differ in their response to injury. Neuroci Lett 72:233-238.

Stoll G, Griffin JW, Li CY, Trapp BD (1989) Wallerian degeneration in the peripheral nervous system: participation of both Schwann cells and macrophages in myelin degradation. J Neurocytol 18:671-683.

Trapp BD, Haucr P, Lcmkc G (1988) Axonal rcgulation of myelin protein mRNA levels in actively myelinating Schwann cells. J Neurosci 8:3515-3521.

Weinberg HJ, Spencer PS (1975) Studies on the control of myelinogenesis. I. Myelination of regenerating axons after entry into a foreign unmyelinated nerve. J Neurocytol 4:395-418.

Weinberg HJ, Spencer PS (1976) Studies on the control of myelinogenesis. II. Evidence for neuronal regulation of myelin production. Brain Res 113:363-378.

Weller RO, Cervós-Navarro J (1977) Pathology of peripheral nerves. London: Butterworths.

White FV, Toews AD, Goodrum JF, Novicki DL, Bouldin TW, Morell $P$ (1989) Lipid metabolism during early stages of Wallerian degeneration in the rat sciatic nerve. J Neurochem 52:1085-1092.

Winter J, Mirsky R, Kadlubowski M (1982) Immunocytochemical study of the appearance of $\mathrm{P} 2$ in developing rat peripheral nerve: comparison with other myelin components. J Neurocytol 11:351362.

Yao JK, Windebank JF, Poduslo JF, Yoshino JE (1990) Axonal regulation of Schwann cell glycolipid biosynthesis. Neurochem Res 15: 279-282. 